\title{
Bilateral carotisdisseksjon
}
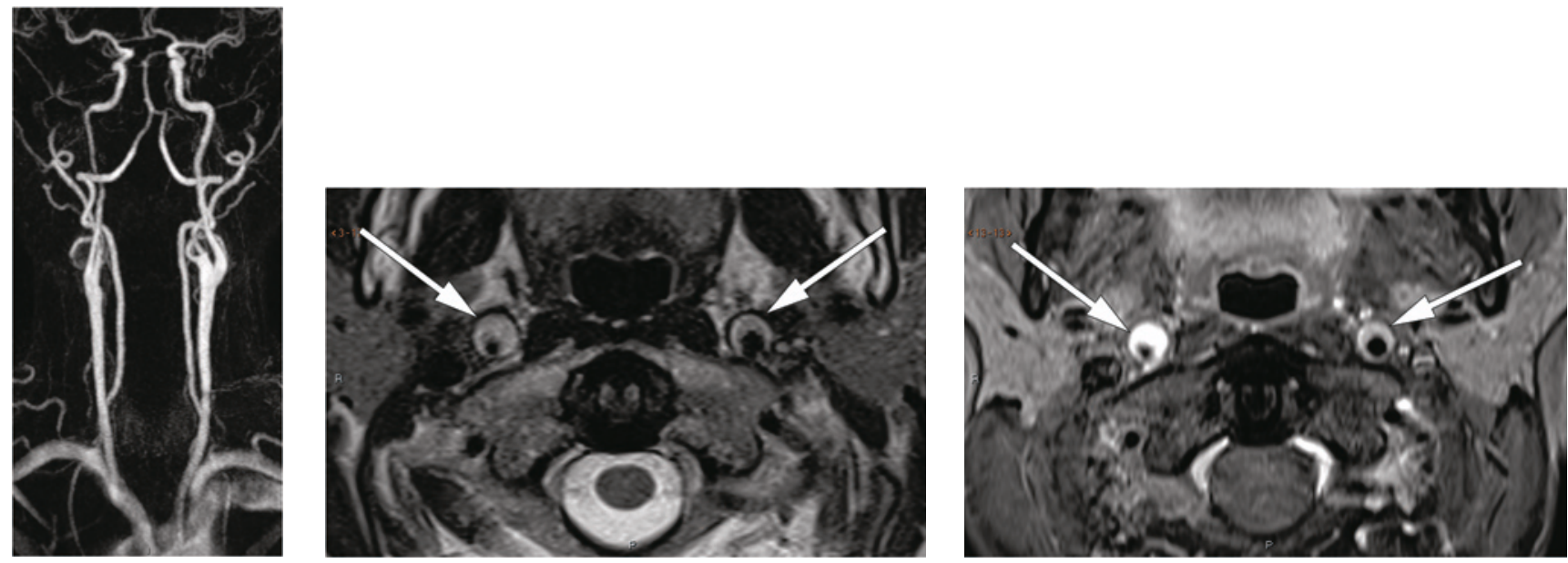

En frisk og veltrent mann i 50-årene oppsøkte øyelege fordi han under en skitur hadde fått episoder med flimring og en følelse av press på høyre øye samt forbigående tinnitus i venstre øre. En uke før det aktuelle hadde han hatt en forkjølelse med intense hosteanfall. Ved undersøkelse ble det bemerket hovent øyelokk og miose høyre øye. Pasienten ble lagt inn i nevrologisk avdeling for videre utredning.

Nevrologisk undersøkelse avdekket Horners syndrom. CT-angiografi viste fortykket karvegg i begge a. carotis interna, mest uttalt på høyre side, fra like over bifurkaturen til skallebasis. MR-angiografi og T2-vektede bilder bekreftet bilateral carotisdisseksjon, med minste lumendiameter $2 \mathrm{~mm}$ på høyre side (bildet til venstre og bildet i midten). Fettsupprimerte T1-vektede bilder (bildet til høyre) viste høyt signal i arterieveggene, forenlig med intramurale hematomer.

Hosteattanfallene i kombinasjon med fysisk aktivitet ble vurdert som sannsynlig årsak til disseksjonen. Risikoen for hjerneinfarkt ble vurdert som høy, og pasienten ble behandlet med acetylsalicylsyre $75 \mathrm{mg}$ og klopidogrel $75 \mathrm{mg}$ i fire måneder, deretter monoterapi med acetylsalisylsyre i to måneder. Behandlingen ble avsluttet da MR-kontroll viste fullstendig normalisering av halskarene. Pasienten hadde fortsatt en lett anisokori, men var ellers symptomfri.

Årlig insidens av carotisdisseksjon angis til 1,7 per 100000 (1). Bilateral disseksjon forekommer sjeldnere. Disseksjon kan føre til hjerneslag eller TIA. Pasienten har ofte lokale smerter på halsen eller hodepine $(60-90 \%$ av tilfellene) og Horners syndrom (ca. $25 \%$ av tilfellene) (1). De vanligste årsakene til disseksjon er mindre traumer (40\%) eller mekaniske triggere i forbindelse med fysisk aktivitet (2). Tidlig radiologisk diagnostikk med CT- eller MR-angiografi og behandling med platehemmer eller antikoagulasjonsmidler er viktig for å forebygge hjerneinfarkt. Det er ikke dokumentert at antikoagulasjonsmidler er bedre enn platehemmere (3).

Pasienten har gitt samtykke til at artikkelen blir publisert.

\section{Karl-Friedrich Amthor}

karl-friedrich.amthor@vestreviken.no

Nevrologisk avdeling

Drammen sykehus

\section{Anniken Haslund}

Avdeling for bildediagnostikk

Drammen sykehus
Karl-Friedrich Amthor (f. 1950) er spesialist i nevrologi, dr.med. og seksjonsoverlege.

Forfatter har fylt ut ICMJE-skjemaet og oppgir ingen interessekonflikter.

Anniken Haslund (f. 1967) er spesialist i radiologi og seksjonsoverlege.

Forfatter har fylt ut ICMJE-skjemaet og oppgir ingen interessekonflikter.

\section{Litteratur}

1. Lee VH, Brown RD Jr, Mandrekar JN et al. Incidence and outcome of cervical artery dissection: a population-based study. Neurology 2006; 67: 1809-12.

2. Engelter ST, Grond-Ginsbach C, Metso TM et al. Cervical artery dissection: trauma and other potential mechanical trigger events. Neurology 2013; 80: 1950 - 7 .

3. Gensicke H, Ahlhelm F, Jung S et al. New ischaemic brain lesions in cervical artery dissection stratified to antiplatelets or anticoagulants. Eur J Neurol 2015; 22: 859-65, e61.

Mottatt 5.9. 2016, første revisjon innsendt 7.12. 2016, godkjent 3.1. 2017. Redaktør: Kaveh Rashidi.

> Se lederartikkel side 166 .

Engelsk oversettelse på www.tidsskriftet.no 